\title{
STEM starts early: Views and beliefs of early childhood education stakeholders in Tanzania' ${ }^{1}$
}

\author{
Laurent Gabriel Ndijuye*, Pambas Basilius Tandika**
}

\begin{abstract}
For about a decade, Tanzania has intensely focused on developing literacy and numeracy skills in pre-primary and early grades programs. Recently, the attention has shifted towards the significance of teaching Science, Mathematics, Technology and Science (STEM) in the early years. To enhance the $21^{\text {st }}$ century skills necessary for building a middle income and knowledge-based economies, the existing empirical evidence emphasizes the need for STEM education starting from pre-primary level. This paper aims to unpack the state of the STEM education in pre-primary education in Tanzania. By using homogenous purposive sampling, two policy-makers, three ECE academics, eight school principals, and eight pre-primary teachers from rural and urban public schools were recruited. Data were collected by interviews, semi-structured survey questionnaires, and documentary analyses. Though there was consensus among ECE stakeholders that children should be exposed to STEM environments as early as possible, findings indicated that even among ECE practitioners, there is a very vague understanding of what entails of STEM education in ECE. Further, while teachers were aware and guided to facilitate science and mathematics education, they were not aware and there were no specific policy briefs/circular instructions on how to facilitate Technology and Engineering education in ECE. The paper concludes with suggestions on how to integrate STEM in early childhood education, especially for Tanzania.
\end{abstract}

\section{Article History}

Received: 09 November 2019

Accepted: 11 January 2020

\section{Keywords}

Early childhood education; STEM in ECE; Tanzania;

ECE stakeholders;

Stakeholders' views and

beliefs

\section{Introduction}

There is sufficient research evidence that the scientific dispositions demonstrated by adults have their roots in early childhood (Edwards, Gandini, and Forman, 1998; Heckman, 2006; Katz, 1999). According to Katz (1999), dispositions are mental inclinations that make an individual respond in specific ways under specific conditions. Some of the typical examples of dispositions include creativity and curiosity (Bowman, Donovan, and Burns, 2001; Stylianidou et al., 2018). For one to develop scientific dispositions, one needs to receive experiences that stimulate and nurture specific mental habits required for scientific thinking (Beghetto and Plucker, 2006). In this paper, we argue that while the current efforts by the government of Tanzania to enhance science and technology tend to target education levels other than early childhood education, more results that are positive would come from a focus on early childhood education.

The need for developing STEM dispositions among young children is a theme whose coverage in the literature is quite high (Beghetto and Plucker, 2006; Doryan, Cautam, and Foege, 2002; Ndijuye and Rao, 2019; Pasnik and Hupert, 2016). While education stakeholders in developing countries are reported to direct most of the resources towards improvements of education offered in levels other than early childhood education (Doryan et al., 2002), the critical window of opportunity is lost and consequently not much can be expected from such investments (Heckman, 2006; Ndijuye and Rao, 2019).The foundations

\footnotetext{
${ }^{1}$ This paper was orally presentedThe $2^{\text {nd }}$ International Conference on Innovative Education and Policy Reforms for Industrial Economy in Africa. The conference was held in Dodoma - Tanzania on 08th to 09

* The University of Dodoma, College of Education, Dodoma, Tanzania, e-mail: buritojr1980@yahoo.com, ORCID: $\underline{\text { https://orcid.org/0000-0001-7712-6814 }}$

** The University of Dodoma,College of Education, Dodoma, Tanzania, e-mail: tpambas@gmail.com, ORCID: https://orcid.org/0000-0001-8267-7493 
for STEM dispositions aredeveloped early in children's lives and forward-looking education systems capitalize on investment in this level of education (Duncan et al., 2007). No wonder, the recent surge of interest in the design and implementation of early childhood programmes targeting to lay strong scientific foundations in Science, Technology, Engineering and Mathematics (STEM) has received enormous attention across the world (see Pasnik and Hupert, 2016). This paper presents an argument that if Tanzania wants to prepare scientists for the future, a focus on early childhood education is inescapable. We argue this by targeting improvements in young children's science laboratories.

\section{Tanzania Education System}

The URT follows the 1(2)-6-4-2-3+ formal educational model, which includes one (or two)years of pre-primary education, 10 years of compulsory basic education (six primary and four lower secondary), two years of upper/high secondary, and three or more years of tertiary. The system evolved from the inherited 4-4-4-4+ colonial education system. With Tanzania's rapid economic growth and social changes, and technological advancements throughout the world, by 2003 it was obvious Tanzania's existing education policy was not bringing the desired results. The Education and Training Policy (ETP), (Ministry of Education \& Culture [MOEC], 1995) targeted increased access to education without compromising the quality thereof, and to focus on issues related to inclusiveness, class sizes, improved teacher training, and attrition issues (Ministry of Education and Vocational Training [MoEVT], 2015). As such, educational practitioners had started to argue for changing the education policy to meet new demands.

\section{STEM Education in Early Childhood in Tanzania}

While teacher education and professional development in the fields of mathematics and science has played significant contributions in the preparation of young children ready for schooling, establishment of science laboratories for children's science learning has recently occupied a central position in research (Eshach and Fried, 2005; Watters, Diezmann, Grieshaber, and Davis, 2000). Overall, the introduction of science laboratories in early childhood classrooms is built on the premise that what happens to the child during early childhood lasts for a lifetime (Black et al., 2016) and that early childhood education contributes to a sustainable society (Pramling and Kaga, 2008). Tanzania would further be a strategy for improving the learning environment for children to explore and experiment on their free will.

Although Tanzania has demonstrated significant efforts to improve early childhood education (MoEVT, 2015; Mtahabwa, 2009, 2010; Ndijuye and Rao, 2018; Tandika and Ndijuye, 2019a), there is sufficient evidence that more effort is needed to improve this education sub-sector in general and science learning in particular. Overall, most early childhood stakeholders in Tanzania have limited understanding of what constitutes best practices in early childhood education and the benefits therefrom (Mtahabwa, 2014; Ndijuye, 2019). In this broad context, it is not surprising to find plans and activities targeted to strengthen scientific dispositions in young children less promising.

The research base in the field of early childhood education in Tanzania indicates that while studies in early childhood policy (see for example, Mtahabwa, 2007; Ndijuye and Rao, 2018; Tandika and Ndijuye, 2019b), and those targeting curriculum and pedagogy (Libent, 2015; Machumu, 2013), have received adequate attention, focus on specific issues in early childhood curriculum areas - STEM education in our case; has received insufficient research attention. As this remains the case, empirical evidence suggests that Tanzania's future in the field of STEM will be problematic unless deliberate interventions are planned and implemented to rectify the current situation (Semali and Mehta, 2012; Tandika and Ndijuye, 2019a). This paper could contribute much to that end.

\section{Objectives of the Study}

This study was guided by the following objectives:

1) Explore perceived beliefs and views of teachers on the current status of STEM education in Tanzania, 
STEM starts early: Views and beliefs of early childhood...

2) Assess pre-primary school teacher's experiences in teaching and learning of STEM in early childhood education;

3) Examine challenges faced by pre-primary teachers in facilitating STEM dispositions in Tanzania.

\section{Method}

\section{Research Approach and Design}

The study employed a qualitative research approach with a phenomenological design. This is a design within the interpretivist paradigm that investigates different ways in which people experience something or think about something (Bowden, 2005). This design allowed the researchers to locate commonalities of lived experiences (Patton, 2009) of pre-primary stakeholders related to STEM education in Tanzania

\section{Sampling Technique and Sample Selection}

Given the specific status and circumstances of STEM education in Tanzania, participants of the current study were those from schools selected to participate in the project titled "Strengthening foundations for scientific dispositions in Tanzania through improvements in young children's science laboratories". Participants were selected using homogeneous sampling technique to obtain insights and understanding of the status, beliefs, challenges and perceived future of STEM education in Tanzania.

Though the idea of having some kind of childcare centres was conserved in 1982, pre-primary education in Tanzania is relatively a new phenomenon. As such, two policy-makers, three ECE academics, eight school principals (four were from public schools in urban area and four from public schools located in rural area), and from each school, one pre-primary teacher (Total of eight teachers) from rural and urban public schools participating in the project were purposively recruited and involved in the study. Given the objectives of the current study, the selected sample size was large enough to allow triangulation of data sources or informants (Onwuegbuzie, Leech, and Collins, 2012), and data collection methods (Patton, 2009) hence, saturation of analysed data (Creswell, 2012).

Informants' preliminary information.

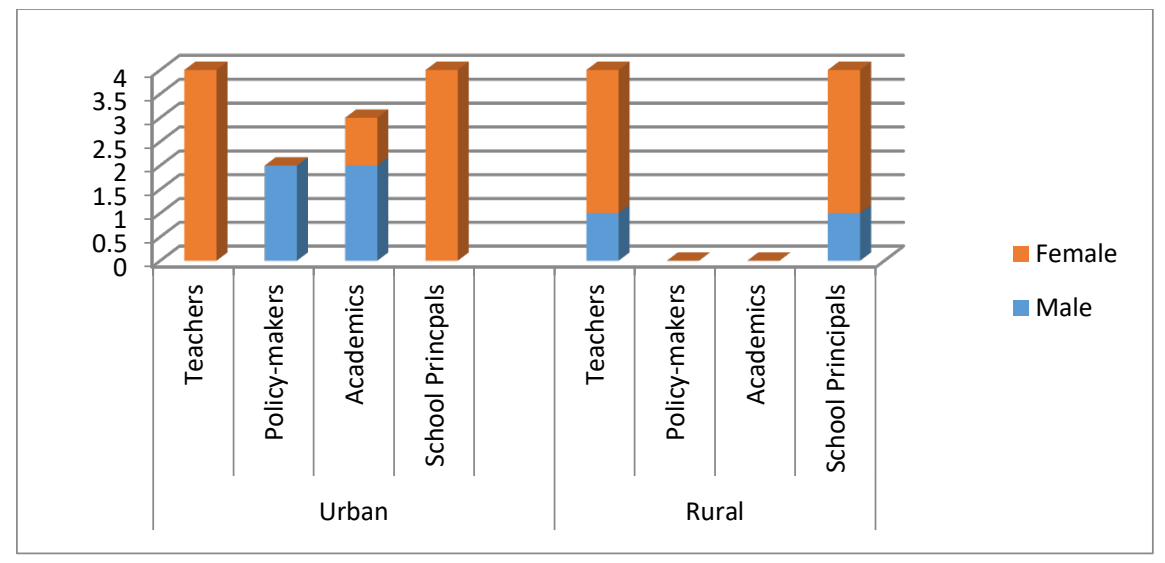

Figure 1: Informants' distribution by Gender and Urbanicity

\section{Informants' educational characteristics}

As indicated in the Figure 2 below, teachers in the visited schools had educational qualifications that made them employable by the government serve in public schools. Though all of them had educational qualifications ranging from teaching certificate to Bachelor of Education, however, none had qualifications to teach at pre-primary level. Most of them reported to have attended short in-service training organized by the government to learn about teaching and learning strategies for the pre-primary children, instructional materials preparation, and preparing learning environment for effective and efficient learning to occur. 
The in- service training courses attended ranged between ten days (five teachers) and one year (two teachers). The other teacher had attended one year of pre-service training on early childhood education in a private college in Dodoma City. Regarding their working experience at pre-primary level, five teachers had less than a year, while the remaining three had teaching experience in early child hood education ranging between one to two years. Teachers revealed that the age of children ranged between 48 to 72 months.

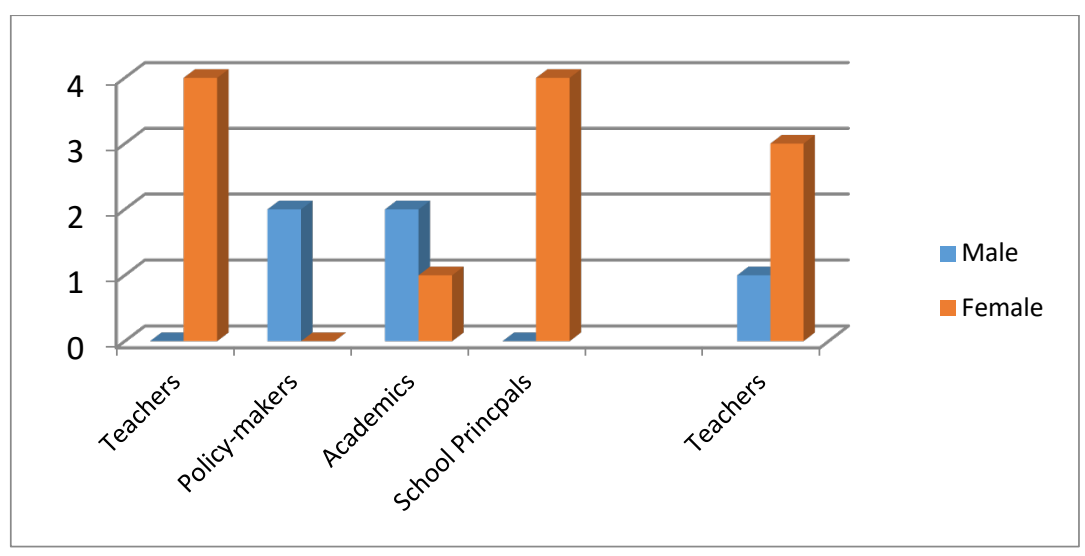

Figure 2: Informants distribution by Gender (Source: Field data, 2019)

\section{Study Area and Context}

In 2018, there were 1,340,090 pre-primary pupils enrolled in Tanzania, out of an eligible pool of 1,535,000 pre-primary-aged children. Among those enrolled, 63 percent were in rural areas, while the rest were living in urban or sub-urban centres. In the same year, there were 8,354 qualified pre-primary schoolteachers, making the teacher-pupils' ratio 1:124 compared to a 1:25 official and international standard ratio (Ministry of Education, Science \& Technology [MEST], 2017). However, most of the qualified teachers preferred to reside and work in urban areas, resulting in lower teacher-child ratios in rural preprimary schools (Ndijuye and Tandika, 2019). The exact number of pre-primary teachers in rural areas is still unknown.

\section{Data Collection Tools}

This study triangulated interviews, semi-structured survey questionnaires, and documentary analyses in collecting required data. Due to its flexibility and time-efficiency, semi-structured survey questionnaires were used with schoolteachers. Policy-makers and pre-primary school principals were individually interviewed. Classroom setting was surveyed by using semi-structured observation kit which was section in the survey questionnaires. The targeted documents were the current Education and Training Policy, pre-primary guideline, pre-primary syllabus and teachers' lesson plan. The predominantly qualitative methods were used to reduce the risk of misinterpretation by informants. The techniques provided a chance of explaining the purpose of the study and clarifying queries raised during the course of discussion (Creswell, 2012). Also, these techniques permitted the establishment of rapport and cooperation between the authors and the informants. This was essential in enabling informants to reveal their views and beliefs in their own words (Creswell, 2009; Patton, 2009).

\section{Data collection procedure}

The data collection process involved face-to-face conversations between the researchers and informants where information was noted down in the field notebook complimented by a tape recorder. Later, the responses were compared with those of other groups in the study. For this study, the targeted documents were existing pre-primary education policy briefs and documents. The researchers decided to use this method because these documents could be secured quickly and easily, and covered a wider geographical area and longer reference periods without much cost (Creswell, 2012; Punch, 2005). Further, the selected policy documents and briefs were selected based on the criteria that they informed about current status of ECE in general and pre-primary STEM education in particular. 


\section{Ethical Issues}

Ethical issues were observed by requesting permission and consent from National Bureau of Statistics, which oversees all research activities in the country, and the University of Dodoma where the researchers are attached. Further, the collected information from each participant was assigned pseudonyms as part of concealing participants' identities. Finally, as part of research ethical conduct; the researchers consulted the school authorities to obtain their consent to include their respective teaching staff in the study. Confidentiality wasobserved by assigning passwords to files of softcopy data, and unauthorized person had no access to the collected hard and softcopy data.

\section{Data Analyses}

Data were subjected to interpretational analyses by involving systematic set of procedures to code and classify qualitative data to ensure that important constructs, themes and patterns emerge (Miles and Hubberman, 1994). Specifically, the raw data obtained from semi-structured questionnaires and interviews were coded to obtained relevant texts, repeating ideas, themes, theoretical constructs, research concerns and theoretical narratives. From repeating ideas, themes and sub-themes were developed. Themes were organized into abstract ideas or theoretical constructs and later developed into theoretical narratives (Patton, 2009) which were used to bridge between the concern of researchers and participants' subjective experiences using their own words (Creswell, 2012). Further, some quantitative data were descriptively analysed to respond to some parts of the presented research question and concerns.

In analysing documents, the following two issues guided how themes were developed: (a) how information was presented, and (b) the status of the policy brief/resolution/by-law/decision. In order to maximize objectivity, communicability, transparency, and coherence techniques were deployed (Auerbach and Silverstein, 2003). Specifically, the authors triangulated data sources, data collection instruments, and bracketed all of their previous understandings, beliefs and assumptions during data analyses (Onwuegbuzie et al., 2012). Equally important, the data analyses processes were jointly done by the two authors.

\section{Inter-rater Reliabilities}

The two authors with doctorates (PhD) degrees in Early Childhood Education jointly collected and analyzed data. The first author coded the field notes to categorize patterns and constructs of differences in the participants' views. To establish inter-rater reliability, 30 percent of the field notes were coded independently by the co-author, and inter-rater reliability calculated by the percentage of agreement among the three raters; at the end, 90 percent consensus was reached.

\section{Findings}

\section{Perceived Beliefs and Views of Stakeholders on the Current Status of STEM Education in Tanzania}

This study intended to find out views and beliefs of pre-primary teachers on the status of science, technology, engineering and mathematics education in Tanzania. The authors assumed that there should be some dominant views and beliefs among pre-primary teachers about STEM education in Tanzania. Two sub-themes were developed, namely, teachers' beliefs about STEM education in pre-primary level, and teachers' views about STEM education at the pre-primary level.

Under the sub-theme about pre-primary teachers' beliefs about STEM education in Tanzania, 7 $(87.5 \%)$ teachers revealed beliefs that pre-primary children should be exposed to STEM environment to build its dispositions for future success in this area. They further indicated beliefs that the foundations for future success in STEM programs solely depended on the experiences gained during the early years. One of them said:

\footnotetext{
Most of the children in public schools come from lower SES families. The school is the only place they get some exposures on various knowledge and skills - including STEM dispositions. As such, for the children's future success in STEM programs, it is very important to expose them as early as in pre-primary stage.
}

One teacher believed that pre-primary children do not need exposure on STEM dispositions because 
children are born with intellects that enable them to learn anything at any stage in life. To him, pre-primary children are too young to be exposed to complex STEM disposition, they still need time to grow and enjoy their childhood. In his own words, he said:

Given its complexities, STEM education and its disposition is such a heavy burden. Pre-primary children are too young to be exposed to STEM. They still need time to mentally and physically grow before embarking in such laborious tasks. At this level, it is good for children to learn to read before they read to learn.

Further, some teachers were of the view that facilitating STEM disposition among pre-primary children contradicts parental and school authorities' expectations to have children learn basic literacy and numeracy skills. Pre-primary teachers revealed that parents, school boards, and the communities around looks forward to having literate and numerate pre-primary children. As such, developing STEM dispositions among pre-primary children is considered a waste of time. One teacher revealed that:

While children are eager to learn STEM dispositions, parents want them to learn reading and writing as early as possible and so are the school authorities. If you (a teacher) do not teach them such skills, you may find yourself in trouble.

An interesting finding was the revelation that some school principals did not consider classroom arrangement and organization as an important component in facilitating STEM disposition among preprimary children. Separately, the researchers observed classroom arrangements and later asked teachers' views about the best classroom structure, which may enhance children's dispositions of STEM learning. One of them revealed that:

Given the importance of STEM education in modern world, we need to equip pre-primary children with a very strong STEM foundation. This can be done in any environment and context. For our context, lecturing is better because these children do not know anything about STEM, so how can I share and exchange STEM knowledge with them?

Findings from the analysed documents indicated that there are neither specific policy briefs nor circular instructions on how teachers should facilitate STEM education in the early years. The current preprimary syllabus and teacher's guide (Kiongozi cha Mwalimu) does not have specific instruction on how to facilitate STEM dispositions in young children. The existing pre-primary syllabus and teacher's guide has specific instruction on how to facilitate Mathematics foundations such as early number concepts and basics of mathematics.

While there was consensus among ECE academics about almost non-existing STEM disposition in ECE in Tanzania's education system, policy-makers were of the view that STEM disposition is critically important at pre-primary level of education, and it should be given equal consideration and treatment when formulating and financing other domains such as literacy and physical development. However, school principals considered viewed ECE as a preparatory class for grade 1, though not a necessary level in education system. As, STEM disposition was considered as "bombarding children" with a lot of concepts unnecessarily. One of them revealed the following:

If you look at the current curriculum, pre-primary children are already overwhelmed with a lot of things to study. I don't think we need to add-up more things for them. Remember, they (pre-primary children) are still too young to start learning complex technology and engineering concepts. I think numeracy and science concepts are enough at this level.

\section{Teachers' Experiences in Teaching and Learning of STEM at Pre-primary Level}

Some teachers (6 of them) reported to be aware of the teaching and learning of science and math than technology. In their experience and understanding, they experienced that the two subjects (science and math) are among the six overarching competencies underlying the pre-primary education curriculum. Two of them were hesitant and seriously concerned that teaching and learning technology for pre-primary children will be a premature activity. They established that equipment's/materials involved in teaching and learning of technology are so advanced and sophisticated for the children to learn. One of them confided that:

I do not teach my children/pupils technology because it is mostly based on globalization, which tends to influence

children negatively and become addicted with technological equipment, hence pay less to caregivers. 
STEM starts early: Views and beliefs of early childhood...

In contrast, few pre-primary teachers revealed to teach technology in different areas of their lessons. One of them said that:

"Normally I teach technology by integrating concepts/ activities in every session and learning occasion. For instance, moulding different shapes using mud or boxes to make cars and/or balls.

Unlike limited understanding and poor experiences on teaching and learning technology, researchers learnt that science and math's was learnt and taught well. One of them reported that:

"I teach science by requiring children to mention things found in and outside the classroom including those found at home."

Through identification of things found in different environment (home and school), teachers believe that they develop children in addition to familiarizing with the environment; they also learn to conserve the environment and able to identify things that are dangerous to their life. Teachers identified things that could harm children are those with sharp edges such as nails. Other activities includedwashing their clothes are cleaning the school and home compounds, practice cleaning utensils, tools/equipment they use in playing/filling the land, and watering garden.

Health practices such as children's wearing shoes when going to toilet to protect them from direct contact with bacteria that could cause infectious diseases, enabled them to develop scientific knowledge and skills related to diseases and good health practices. Scientific disposition is developed and enhanced at pre-primary level when children are involved in scientific acts like collection of insects and observe to identify parts and roles of each part. Broadly, children learn to keep their health by doing health-related activities (cleaning utensils, cleaning their shoes, wearing shoes and ensuring that they do not go to the toilet bare feet; and also cleaning their body in general)and learn about things (both harmful and useful) found in their environment (home and school).

\section{Classroom Organization}

As part of the study, the researchers surveyed variations in classroom arrangements conducted before interviewing teachers. They came-up with the following findings:

1. Talking walls, that's most of the classroom had some pictures (teacher made) of different sciencerelated things such as fruits, numbers, letters and objects like people or houses; other pictures were of flowers, trees and some furniture.

2. Traditional classroom organization in which arrangement of desks was in rows and columns that made all children face the chalkboard from which teachers lectured and facilitated learning. This implies that learning was more of the whole group discussion with occasional learner-teacher partner interaction. Perhaps, the observed classroom arrangement could be due to extremely large number of children accommodated in the same room for learning.

3. The dominant teaching and learning method was lecturing. All of the observed pre-primary teachers preferred to use teacher-centred teaching and learning strategies. This method limited children's interaction with teachers and content. This may have negative implication on children's learning of STEM and other dispositions.

Generally, in all visited schools, the state of the learning environments were poor characterized by limited materials and poor organization to promote face-to-face children discussion.

\section{Teaching and Learning Environments}

There were varying responses regarding the quality of the working environment. About 75 percent of teachers and 80 percent of school principals expressed that the working environments at pre-primary level is poor. They claimed that it's characterized by lack of specific classrooms for pre-primary children and unsupportive climate from school authorities. It was revealed that there was no specific classroom for pre-primary children. As such, they had to shift and change rooms in case any emergency or activity at school. One of the teachers reported that: 
"Almost every other month I had to move from one classroom to the next. For example, whenever there is an examination or tests for upper classes, we (pre-primary teacher and children) have to vacate our classroom for them. I think school authority do not consider pre-primary children as legitimate students of this school hence are least valued"

Limited availability of textbooks to support STEM learning was reported contribute on the state of working environment. Pre-primary teachers reported to have only one copy of textbooks for each overarching competencies. They claimed that though these children have not developed other literacy skills, yet having extra copies of books would help them build strong STEM foundations. Family poverty including failure of caregivers to support their children for early and easy access to school (lack of transport); and poor care in terms of cleanliness, and hunger. This led into children's poor emotional competences such as, inability to bond and interacts with their peers, outburst anger, and isolation.

\section{Challenges facing teaching and learning of STEM in Tanzania}

The researchers were interested to understand challenges facing preschool teachers in effectively facilitating STEM disposition in Tanzania. Informants revealed that (i) Limited working resources (instructional materials, textbooks, desks), (ii) Overcrowded classrooms were the main challenges facing pre-primary schoolteachers.

\section{Limited working resources}

Findings revealed that there were limited numbers of pre-primary books, play materials and childsized desks and tables which, in fact, limiting children to sit and learn comfortably. Consequently, teachers reported that children could inadequately develop fine-motor skills (Holding and using writing materials such as pencil and exercise books) and lacked freedom to move within and outside of the classroom. Further, it was revealed that, even the available desks and tables were insufficient given the large number of children. The adult-sized desks and tables could accommodate between four to five pre-primary children. One of the school principals revealed that:

\footnotetext{
“My school has about 2000 pre-primary and primary children. However, I have only 300 desks, which cannot serve all these children. In such context, the priority is given to examination grades (Examination grades in Tanzania are Grades four and seven). Equally important, though it is important, but I don't have child-sized furniture for preprimary children"
}

\section{Overcrowded classrooms and teacher qualifications}

Informants' responses and classroom observation data revealed that there are too many children occupying the same classroom with mixed ages. In all the observed schools, pre-primary children were found occupying a single room while they are at or above 150. Great number of children in the single room under one or two facilitators, high number of children impacts teacher's initiatives to reach every child to learn about their strength and weakness for appropriate support. Teacher's inability to reach each child during learning is a challenge as there are only 20 minutes allocated for a learning competency among the six they are required to learn. Therefore, in the 20 minutes, it is difficult for the teacher to reach every learner and determine his or her achievement level for scaffolding.

While working environment in terms of inadequate resources and fewer classrooms/ use of one classroom for many children was the major challenge in teaching and learning STEM, children's ability to learn was found to be good hence being not among the challenges impacting effective learning. This implies that children are eager and participate well in learning, as they are knowledgeable on many things that are found in their environment.

The most interesting and perhaps important challenge revealed by teachers was absence of qualified pre-primary teachers. All of the teachers in this study were trained to teach at primary school level - none was trained at pre-primary level. However, school principals reported that they regularly send their preprimary teachers to attended various seminars and workshops related to teaching at this level. However, these in-service training were very rare and did not last more than 7 days each. Nevertheless, something is better than nothing as one teacher revealed the following: 
STEM starts early: Views and beliefs of early childhood...

"I'm a trained primary school teacher with experiences of about 10 years. Now, as you can see, I teach pre-primary class. These are very young children overcrowded in a single classroom of about 182 of them. Teaching them is not the same as teaching more disciplined grade 4 children. Last year I attended a 7-days workshop about teaching literacy at this level. I hope you guys will organize a workshop on how to facilitate STEM learning as well."

The current circular on teachers' scheme of service (2016) instructs that each individual teacher should be assigned responsibilities as par his/her professional qualifications. In other words, teachers trained and qualified to teach at primary level should be appointed and assigned to teach at that specific level. If Tanzania does not have qualified pre-primary teachers to cater for the fastest-growing subsector, it is unlikely to find these unqualified teachers to facilitate STEM dispositions for children in this cohort.

\section{Discussion}

The current study aimed to explore perceived beliefs and views of teachers on the current status of STEM education in Tanzania, assess pre-primary school teacher's experiences in teaching and learning of STEM in early childhood education; and examine challenges faced by pre-primary teachers in facilitating STEM dispositions in Tanzania.

\section{Beliefs and Views of Teachers on the Current Status of STEM Education in Tanzania}

Most of the Tanzanian teachers were of the view that children should be exposed to STEM during pre-primary stage to build a strong foundation for future academic and profession success in STEM fields. This is consistent with other studies which indicated that young children are much more capable of learning STEM concepts and practices than originally thought by the ECD research community (Institute of Medicine [IOM] and National Research Council [NRC], 2015). A growing body of empirical evidences indicates a very strong correlation between early experiences with and exposure to STEM subjects with later success in those subjects and career in those fields (Duncan et al., 2007; Duncan and Magnuson, 2011; IOM and NRC, 2015; Kilbanoff, Levine, Huttenlocher, Vasilyeva and Hedges,2006; Saçkes, Trundle, Bell, and O'Connell, 2011).

Early exposure to mathematics during pre-primary years is said to predict later math achievement even during high school years (Kilbanoff et al., 2006; Saçkes et al., 2011). And the skills gained during the pre-primary years has been said to predict later academic achievements more consistently than early attention and reading skills (Kilbanoff et al., 2006; Saçkes et al., 2011). Early math skills - including reasoning skills is considered to be an integral part of children's development of "learning to learn" skills - such as fostering children's ability to reason and talk about their mathematical thinking (Kilbanoff et al., 2006; STEM Smart, 2013).

Further, available evidence supports children's early exposure to science and technology inquiry (Eshach and Fried, 2005; Kilbanoff et al., 2006; STEM Smart, 2013). Children who are exposed and engage in scientific and technological activities as early as prekindergarten age develop attitudes toward science and technology fields (Osborne, Simon, and Collins, 2003; Saçkes et al., 2011; STEM Smart, 2013). The developed positive attitudes also correlate with later academic achievements in scientific and technological related subjects (Patrick, Mantzicopoulos, Samarapungavan, and French2008; Saçkes et al., 2011). And these children are more likely to pursue STEM expertise and careers later on as adults (Duncan et al., 2007; IOM and NRC, 2015).

In Tanzania, with limited supportive environments for STEM learning, teachers' supportive views and beliefs towards STEM disposition during the early years becomes critical (Semali and Mehta, 2012; Tandika and Ndijuye, 2019a). Teachers' beliefs are critical in children's learning and development (Farell and Ives, 2015; O-saki, 2007; Semali and Mehta, 2012) since their teaching reflects their beliefs (Farell and Ives, 2015; Tam, 2015). This is because pre-primary children develop STEM disposition in informal and formal settings, and by engaging in experiential learning (Osborne et al., 2003; Saçkes et al., 2011).

In Tanzania, the existing education policy and circular documents are silent on how pre-primary children would be exposed to STEM education. One of the indicators of the public seriousness and commitments in addressing needs of a social group is how those needs have been addressed in the existing 
policy and practice documents (Mtahabwa, 2010) and having clear implementation plans to handle and solve the underlying problems facing that group (Mtahabwa, 2010; Ndijuye and Rao, 2018). The fact that pre-primary education policy and practice documents are quiet about how, when, and why children should be exposed to STEM concepts and practice suggest that Tanzania needs to comprehensively integrated approach to this matter.

\section{Teachers' Experiences in Teaching and Learning of STEM at Pre-primary Level}

Findings of the current study revealed that pre-primary teachers in Tanzania had experiences teaching math and science concepts than technology and engineering. This may be rooted in the existing pre-primary curriculum. The analysed documents disclosed that there is neither existing policy brief nor curriculum guideline about STEM education at this compulsory level of education. However, such experiences are not uncommon in early childhood research. While there is a consensus among pre-primary researchers that children come to school with sufficient knowledge about the natural world (Pantoya, Aguirre-Munoz, and Hunt, 2015; Shonkoff and Phillips, 2000), can abstractly and concretely think (IOM and NRC, 2015), but the early technology and engineering realms are less understood and taught (National Association for the Education of Young Children [NAEYC] and Fred Rogers Center for Early Learning and Children's Media, 2012; Pantoya et al., 2015). This may be due to misconceptions among many pre-primary stakeholders that engineering and technology as subjects at pre-primary levelmeans using digital and/or electronic technology, such as touch-screen tablets and construction of block buildings and bridges in a classroom.

It is a well-known fact that STEM dispositions at pre-primary level requires conducive and supportive teaching and learning environments such which facilitates children's hands-on learning (Clements, 2002; Sarama, Lange, Clements, and Wolfe, 2012). These environments include proper classroom organizations, learning corners, and "talking walls". However, findings revealed that preprimary teachers preferred to use traditional, non-interactive methods such as lecturing and demonstrations. This may have unpleasant implications on the STEM foundations for these children. Use of teacher-centred methods may have been partly the result of exceedingly unmanageable class sizes of between 160 to 180 children congested in a single classroom with one or two teaching assistants. It is important to note that in Tanzania the official teacher-child ratio is 1:25 (MEST, 2017).

Further, it was found that most of the teachers serving public pre-primary classes in Tanzania were not trained to cater for this age cohorts. They were trained as primary school teachers - were not even trained to serve early grades children. A growing body of empirical evidences indicates that in most developing countries with limited educational resources, quality of teachers complemented with supportive home learning environment, is a single most important factor in enhancing children's development and learning (Aboud and Hossain, 2010; Melhuish et al., 2008; Ndijuye, 2019). Teacher quality becomes more critical at the foundational pre-primary level, especially for fundamental fields such as STEM (Lauwerier and Akkari, 2015; Tandika and Ndijuye, 2019a). However, it is important to note that something is better than nothing - while Tanzania has successfully improved access to pre-primary services (MEST, 2017), it is now a very high time to focus on quality of services so much so that to improve practices.

\section{Challenges Facing Teaching and Learning of STEM at Pre-Primary Level in Tanzania}

Limited teaching and learning materials such as STEM-related play materials and books were reported to be one of the challenges facing teachers when facilitating STEM dispositions in Tanzania. This challenge is not new in public pre-primary classes in Tanzania (Ndijuye and Rao, 2018; Tandika and Ndijuye, 2019b). Comparatively, it is understandable that public budgetary investment in this subsector is relatively low (Mtahabwa, 2015; Ndijuye and Rao, 2018), and not a priority of most primary school principals (Mghasse and William, 2016; Mtahabwa, 2015). However, scarcity of teaching and learning resources is exceedingly overstated.

For example, while Tanzania has abundant supply of natural and environmental-friendly play 
materials for pre-primary children, teachers tend to poorly improvise such materials to serve specific purpose of the lesson such as STEM dispositions (Mtahabwa, 2015; Tandika and Ndijuye, 2019a). Most of the science concepts can be taught by using Tanzania's exceedingly rich green environments, which are familiar, and fits well into the mental schema of children. Nevertheless, improvisation of teaching and learning materials requires satisfactory teacher's qualifications, commitments and adoptability (Buckler, 2015).

Having an extremely overcrowded classrooms led with lowly qualified teachers is not something to be proud of. While Tanzania has made tremendous gains in broadening access to basic education including pre-primary education (MEST, 2017; Ndijuye, 2019) quality of services for these children is still low. In the context of the current study, quality pre-primary education is conceptualized to refer to both structural and process aspects of quality. The existing pre-primary guidelines instructs 1:25 teacher-child ratio (MEST, 2017), however, the study revealed that on average, there were about 160 children in a single classroom in urban public primary schools served by two teachers, while in rural areas, the average classroom had about 180 children served with only one teacher. Overcrowded classroom may have negative implications on how pre-primary teachers facilitated and children learned STEM dispositions.

\section{Conclusion and Recommendations}

Available empirical evidences suggest that generally Tanzanians have limited exposure to STEM learning. In other words, they struggle to understand why it matters and how it works. At pre-primary level, even important stakeholders of this subsector such as teachers and school principals do not a clear understanding of the importance and processes involved in equipping children with STEM foundations. Providing a clear illustration of a STEM learning program - what participants learn and how they learn it, with what goals and outcomes-sketches a memorable picture that can fill in cognitive gaps.

Therefore, in a context with limited education resources, it is critically important to equip preprimary teachers and school principals with clear understanding of STEM education and its importance to pre-primary children. The findings of this broaden our empirical understanding of the current status of STEM education in one of the low-income contexts and how we can make use of the available limited resources to maximize children's STEM dispositions. Given the socio-economic importance of STEM education, there is a need for more research to examine the best ways to facilitate early STEM dispositions in contexts with limited educational resources coupled with relatively low quality pre-primary teachers. Further, while presence of excellent STEM education policy does not guarantee good practices at classroom level, however, it is a very important milestone in improving children's STEM disposition. Lack of policy and practice guidelines on how to facilitate STEM education among pre-primary children in Tanzania should be addressed. STEM education should be inserted in the existing pre-primary teachers' training curriculum. This should be done while exposing teacher's college tutors to STEM education.

\section{Declarations}

This is an original work by the authors. It is part of the ongoing research project titled "Strengthening foundations for scientific dispositions in Tanzania through improvements in young children's science laboratories"

Acknowledgements: The authors gratefully acknowledge funding support from the Junior Academic Staff Seed Grant by the University of Dodoma - Tanzania.

Authors' contributions: In this paper, authors have equal contributions

Competing interests: To our knowledge, there is no conflict of interests that exists.

Funding: Funding support from the Junior Academic Staff Seed Grant by the University of Dodoma - Tanzania.

\section{References}

Aboud, F., \& Hosain, K. (2010). The impact of pre-primary school on primary school achievement in Bangladesh. Early Childhood Research Quarterly, 26(3), 237-246.

Auerbach, C. F., \& Silverstein, L. B. (2003). Qualitative data: An introduction to coding and analysis. New York: New York University Press. 
Beghetto, R. A., \& Plucker, J. A. (2006). The relationship among schooling, learning, and creativity: "All roads lead to creativity" or "You can't get there from here"? In J. C. Kaufman \& J. Baer (Eds.), Creativity and reason in cognitive development (pp. 316-332). Cambridge: Cambridge University Press. doi:10.1017/CBO9780511606915.019

Black, M. M., Walker, S.P., Fernald, L.H., Andersen, C.T., Digirolamo, A. M.,Lu, C., ... Grantham-McGregor, S. (2016). Early childhood development coming of age: Science through the life course. Lancet, 1, 1-14. doi: 10.1016/S0140-6736(16)31389-7.

Bowden, J. (2005). Reflections on the phenomenographic research process. J. Bowden \& P. Green (Eds.), In Doing developmental phenomenography. Qualitative research methods series. Melbourne, Victoria: RMIT University Press.

Bowman, B. T., Donovan, M. S., \& Burns, M. S. (Eds.). (2001). Eager to learn: Educating our preschoolers. Washington, DC: National Academy Press.

Buckler, A. (2015). Quality teaching in rural Sub-Saharan Africa: Different perspectives, values and capabilities. International Journal of Educational Development, 40(2), 126-133.

Clements, D. H. (2002). Computers in early childhood mathematics. Contemporary Issues in Early Childhood, 3(2), 160-218.

Creswell, J. W. (2009). Research design: A qualitative, quantitative \& mixed method approaches ( ${ }^{\text {rd }}$ ed.). Thousand Oaks CA: Sage Publishers.

Creswell, J. W. (2012). Research design: A qualitative, quantitative \& mixed method approaches (4rd ed.). Thousand Oaks CA: Sage Publishers.

Doryan, A., Cautam, K. C., \& Foege, W. H. (2002). The political challenge: Commitment and cooperation. In M. E. Young (Ed.), Investing in our children's future: From early childhood development to human development (pp. 375-391). Washington D.C.: The World Bank.

Duncan, G. J., Dowsett, C. J., Claessens, A., Magnuson, K., Huston, A. C., Klebanov, P., \& Japel, C. (2007). School readiness and later achievement. Developmental Psychology, 43(6), 1428-1446.

Duncan, G. J., \& Magnuson, K. (2011). The nature and impact of early achievement skills, attention skills, \& behavior problems. In G. J. Duncan \& R. J. Murnane (Eds.), Whither Opportunity (pp. 47-69). New York: Russell Sage.

Edwards, C., Gandini, L., \& Forman, G. (1998). The hundred languages of children: The Reggio Emilia approach - advanced reflections ( $2^{\text {nd }}$ ed.). London: Ablex Publishing Corporation.

Eshach, H., \& Fried M. N. (2005). Should science be taught in early childhood? Journal of Science Education and Technology, 14(3), 315336 .

Farell, T.S.C., \& Ives, J. (2015). Exploring teacher beliefs and classroom practices through reflective practice: A case study. Language and Teaching Research, 19(5), 594-610.

Heckman, J. J. (2006). Investing in disadvantaged young children is an economically efficient policy. Paper Presented at the Committee for Economic Development/The Pew Charitable Trusts/PNC Financial Services Group Forum on "Building the Economic Case for Investing in Preschool", New York. Retrieved from: http://www.ced.org/docs/report/report_2006heckman.pdf.

Institute of Medicine (IOM) \& National Research Council (NRC). (2015). Transforming the workforce for children birth through age 8: A unifying foundation. In Allen, L., \& Kelly, B. B. (Eds.). Washington, DC: National Academies Press.

Katz, J.L. (1999). Games and toys in teaching of science and technology education: Document series No. 29, June 17. Paris: UNESCO

Kilbanoff, R. S., Levine, S. C., Huttenlocher, J., Vasilyeva, M., \& Hedges, L. V. (2006). Preschool children's mathematical knowledge: The effect of teacher "math talk". Developmental Psychology, 42(1), 59-69.

Lauwerier, T., \& Akkari, A. (2015). Teachers and the quality of basic education in sub-Saharan Africa. Education Research and Foresight: Working Papers Series, no. 11.

Libent, D. (2015). Determinants of parents' satisfaction with the quality of pre-primary education in Ilala District, Dar es Salaam Region, Tanzania (Published PhD Thesis). Kenyatta University, Nairobi, Kenya.

Machumu, M. A. M. (2013). Promoting children's learning through quality pre-primary education in Tanzania (Unpublished PhD thesis).University of Dar es Salaam, Dar es Salaam, Tanzania.

Melhuish, E. C., Phan, M. B., Sylva, K., Sammons, P., Siraj-Blatchford, I., \& Taggart, B. (2008). Effects of the home learning environment and preschool centre experience upon literacy and numeracy development in early primary school. Journal of Social Issues, 64(3), 95-114.

Mghasse, N. E., \& William, F. (2016). Practices and challenges in the provision of pre-primary education in Tanzania. African Research Review, 10(1), 1-16.

Miles, M. B., \& Hubberman, A. M. (1994). Qualitative Data Analysis. London: Sage.

Ministry of Education and Culture (MOEC). (1995). Education and Training Policy. Dar es Salaam: Government press.

Ministry of Education and Vocational Training (MoEVT). (2015). Education and Training Policy. Dar es Salaam: Government press.

Ministry of Education, Science and Technology (MEST). (2017). Basic education statistics in Tanzania. Dar es Salaam: Government Press. 
STEM starts early: Views and beliefs of early childhood...

Mtahabwa, L. (2007). Pre-primary educational policy and practice in Tanzania: Observations from urban and rural pre-primary schools (Unpublished PhD Thesis). The University of Hong Kong, Hong Kong.

Mtahabwa, L. (2009). Early Childhood Development and Care in Tanzania: Challenges for the future. Early Child Development and Care, 179(1), 55-67.

Mtahabwa, L. (2010). Provision of pre-primary education as a basic right in Tanzania: Reflections from policy documents. Contemporary Issues in Early Childhood, 11(4), 353-364.

Mtahabwa, L. (2014). Promoting the rights to early childhood care and education in Tanzania: A baseline study. A Consultancy Report Funded by TEN/MET/ANCEFA/Pestalozzi Children's.

Mtahabwa, L. (2015). Aligning pre-primary teacher education programmes to policy and curricula in Tanzania. Journal of Education, Humanities and Sciences, 4(2), 1-28.

National Association for the Education of Young Children [NAEYC] \& Fred Rogers Center for Early Learning and Children's Media. (2012). Technology and interactive media as tools in early childhood programs serving children from birth through age 8 . Retrieved from: http://www.naeyc.org/content/technology-\&-young-children

Ndijuye, L.G. (2019). Developing conflict resolution skills among pre-primary children: Views and practices of parents and teachers in Tanzania. Global Studies of Childhood. doi:2043610619832895

Ndijuye, L. G., \& Rao, N., (2018). Pre-primary education policy in Tanzania: Does it meet the educational needs of newly naturalized refugee children? Global Education Review, 5(4), 36-54.

Ndijuye, L. G., \& Rao, N., (2019). Early reading and mathematics attainment of children of recently naturalized refugees in Tanzania. International Journal of Education Development, 65, 183-193.

Ndijuye, L.G., \&. Tandika, P. B. (2019). Timely promotion as a motivation factor for job performance among pre-primary school teachers: Observations from Tanzania. Journal of Early Childhood Studies, 3(2), 440-456.

Onwuegbuzie, A.J., Leech, N.L., \& Collins, K.M.T. (2012). Qualitative analysis techniques for the review of literature. The Qualitative Report, 17(56), 1-28.

O-saki, K., (2007). Science and mathematics teacher preparation in Tanzania: Lessons from teacher improvement projects in Tanzania: 1965-2006. NUE Journal of International Cooperation, 2(1), 51-64.

Osborne, J., Simon, S., \& Collins, S. (2003). Attitudes towards science: A review of the literature and its implications. International Journal of Science Education, 25(9), 1049-1079.

Pantoya, M.L., Aguirre-Munoz, Z., \& Hunt, E.M. (2015). Developing an engineering identity in early childhood. American Journal of Engineering Education, 6(2), 61-68.

Pasnik, S., \& Hupert, N. (2016). Early STEM Learning and the Roles of Technologies. Retrieved from: http://ltd.edc.org/sites/ltd.edc.org/files/EarlySTEMTechWhitePaper.pdf.

Patrick, H., Mantzicopoulos, P., Samarapungavan, A., \& French, B. F. (2008). Patterns of young children's motivation for science and teacher-child relationship. The Journal of Experimental Education, 76(2), 121-144.

Patton, M. Q. (2009). An introduction to qualitative research (4th ed.). London: Sage Publications Ltd.

Pramling, I., \& Kaga, Y. (2008). The contribution of early childhood education to sustainable society. Paris: UNESCO. Retrieved from: http://unesdoc.unesco.org/images/0015/001593/159355E.pdf.

Punch, K. F. (2005). Introduction to social research: Qualitative and quantitative approaches. London: Sage Publications.

Saçkes, M., Trundle, K. C., Bell, R. L., \& O'Connell, A. A. (2011). The influence of early science experience in kindergarten on children's immediate and later science achievement: Evidence from the early childhood longitudinal study. Journal of Research in Science Teaching, 48(2), 217-235.

Sarama, J., Lange, A., Clements, D. H., \& Wolfe, C. B. (2012). The impacts of an early mathematics curriculum on emerging literacy and language. Early Childhood Research Quarterly, 27(1), 489-502. doi: 10.1016/j.ecresq.2011.12.002

Semali, L. M., \& Mehta, K. (2012). Science education in Tanzania: Challenges and policy responses. International Journal of Education Research, 53(3), 225-239

Shonkoff, J. P., \& Phillips, D. A. (Eds.). (2000). From neurons to neighborhoods: The science of early childhood development. Washington, DC: National Academies Press.

STEM Smart. (2013). Nurturing STEM skills in young learners, PreK-3. Retrieved from: http://successfulstemeducation.org/resources/nurturing-stem-skills-young-learners-prek $\% E 2 \% 80 \% 933$

Stylianidou, F., Glauert, E., Rossis, D., Compton, A., Cremin, T., Craft, A., \& Havu-Nuutinen, S. (2018). Fostering Inquiry and creativity in early years STEM education: Policy recommendations from the Creative Little Scientists Project. European Journal of STEM Education, 3(3), 15-31. doi:10.20897/ejsteme/3875 


\section{Laurent Gabriel NDIJUYE \& Pambas Basilius TANDIKA}

Tam, A. C. F. (2015). The role of a professional learning community in teacher change: A perspective from beliefs \& practices. Teachers ETeaching: Theory \& Practice, 21(1), 22-43.

Tandika, P. B., \& Ndijuye, L.G. (2019a). Integration of the use of ICT in pre-primary classroom pedagogical practices in Tanzania: Stakeholders' views \& practices. Journal of Information \& Learning Sciences, 59(4), 35-59.

Tandika, P. B., \& Ndijuye, L.G. (2019b). Do fathers' involvement in young children's development and learning in the early years important? Experiences from the caregivers in Tanzania. Global Education Review, 6(1), 63-74.

Watters, J. J., Diezmann, C. M., Grieshaber, S. J., \& Davis, J. M. (2000). Enhancing science education for young children: A contemporary Initiative. Australian Journal of Early Childhood, 26(2), 1-7. 